\title{
Effect of SP-B Peptides on the Uptake of Liposomes by Alveolar Cells
}

\author{
D.L. Poelma ${ }^{a}$ F.J. Walther ${ }^{b, c} \quad$ A.J. Waring ${ }^{\text {b, }}$ I.J. Haitsma ${ }^{a} \quad$ L.J. Zimmermann ${ }^{e}$ \\ B. Lachmann ${ }^{\text {a J.F. van Iwaarden }}{ }^{\mathrm{e}}$ \\ a Department of Anesthesiology, Erasmus MC-Faculty, Rotterdam, The Netherlands; ${ }^{\mathrm{b}}$ Los Angeles Biomedical \\ Research Institute, Harbor-UCLA Medical Center, Torrance, Calif., USA; ${ }^{C}$ Department of Pediatrics, Leiden University

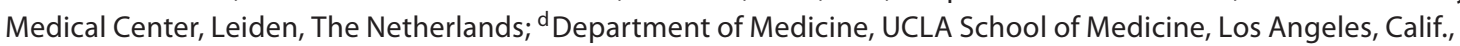 \\ USA; ${ }^{\mathrm{e} D e p a r t m e n t}$ of Neonatology, University Hospital Maastricht, Maastricht, The Netherlands
}

\section{Key Words}

Synthetic peptides · Surfactant, lung

\begin{abstract}
Background: Exogenous surfactant has been accepted worldwide as a therapy of RDS in premature and term infants. Exogenous surfactant is usually derived from lung extracts containing phospholipids and the surfactant proteins SP-B and SP-C. Synthetic peptides of SP-B and SP-C are being tested with the aim to develop a completely synthetic surfactant preparation. Nevertheless, the effects of these peptides on the endogenous surfactant metabolism remain unknown. Objectives: The effect of synthetic SP-B peptides on uptake of surfactant-like liposomes was investigated in alveolar cells. Native SP-B and seven SP-B peptides were included: monomeric and dimeric SP-B ${ }_{1-25}$ (Cys-11 $\rightarrow$ Ala-11), SP-B $63-78$ and Ala-SP-B $63-78$ (Cys-71 $\rightarrow$ Ala-71;Cys-77 $\rightarrow$ Ala77) and their serine mutants. Methods: In vitro, alveolar macrophages (AM) and alveolar type II cells (ATII) were incubated with liposomes containing SP-B or one of its peptides. In vivo, rats received intratracheally various SP-B peptides (SP-B/lipid ratio 1:33 w/w) incorporated in fluorescent surfactant-like liposomes. One hour after instillation, AM and ATII were isolated and cell-associated fluorescence was determined using flow cytometry. Confocal laser microscopy was performed to ensure internalization of the liposomes. Results: In vitro uptake by AM or ATII was not influenced by
\end{abstract}

\section{KARGER}

Fax +4161306 1234 E-Mail karger@karger.ch www.karger.com
(C) 2007 S. Karger AG, Basel

Accessible online at: www.karger.com/neo the SP-B peptides. In vivo, SP-B $\mathrm{B}_{1-25}$ and Ser-SP-B $\mathrm{B}_{1-25}$ increased the uptake by $A M$ whereas dSP- $B_{1-25}$ decreased the uptake. Neither SP-B $\mathrm{B}_{1-25}$ nor dSP-B ${ }_{1-25}$ affected total uptake by ATII. The overall uptake by $\mathrm{SP}-\mathrm{B}_{63-78}$ variants was not changed. Conclusions: Surface-active synthetic SP-B peptides do not interfere with the normal uptake of surfactant by ATII.

Copyright $\odot 2007$ S. Karger AG, Basel

\section{Introduction}

Pulmonary surfactant is essential for normal lung function, and its absence leads to respiratory failure. The presence of endogenous surfactant in the lung is dependent upon a very complex system of production, secretion, formation of lipid monolayer, turnover, re-uptake and recycling. Briefly, after secretion, surfactant unfolds to tubular myelin that is incorporated into the lipid monolayer. During respiration the surfactant in the lipid monolayer is turned over from large surface active aggregates into small inactive surfactant aggregates [1-3]. These small aggregates are removed from the alveolar space by both alveolar macrophages and alveolar type II cells. As de novo synthesis is insufficient to compensate the loss of surfactant, especially in neonates, the alveolar type II cells recycle these small aggregates.

The uptake of small aggregates is influenced by several factors, such as environmental ones [4], lipid consti-
J.F. van Iwaarden, $\mathrm{PhD}$

Department of Neonatology, Academic Hospital Maastricht

PO Box 5800

NL-6202 AZ Maastricht (The Netherlands)

Tel. +31 43387 7832, Fax +31 43387 5246, E-Mail FVIW@paed.azm.nl 


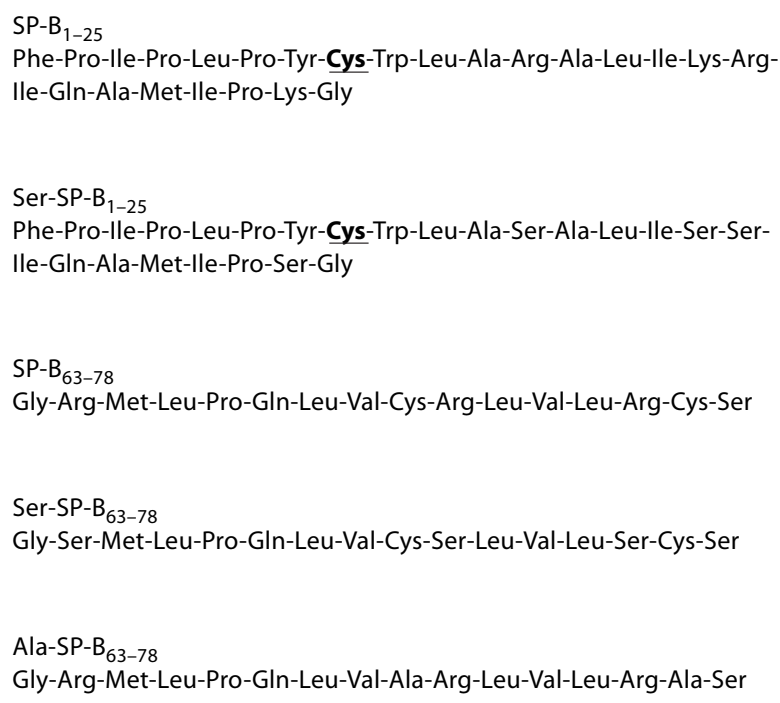

Fig. 1. Peptide sequences of the SP-B peptides and their serine mutants. The SP-B $\mathrm{B}_{1-25}$ homodimer consists of two $\mathrm{SP}-\mathrm{B}_{1-25}$ monomers which are disulfide-linked at Cys8.

tution and surfactant proteins, mainly SP-A, SP-B and SP-C. Especially SP-A and to a smaller extent SP-C have been demonstrated to stimulate the uptake of surfactant lipids by alveolar type II cells and macrophages [5-13]. However, the effects of SP-B on lipid uptake are more complex. SP-B can increase the uptake of liposomes in vitro [10, 14-17], but also inhibit SP-C mediated uptake by alveolar type II cells $[9,10]$.

Exogenous surfactant has been accepted worldwide as a therapy of RDS in premature and term infants, and the use of surfactant therapy for adults is under discussion. Exogenous surfactant is usually derived from lung extracts containing phospholipids and the two hydrophobic surfactant proteins SP-B and SP-C; both these surfactant proteins play an important role in the surface tension lowering properties of surfactant [18-20]. Moreover, the need of the two proteins is emphasized by the fact that absence of SP-B is lethal $[21,22]$. Synthetic peptides of SP-B and SP-C based on the known human amino acid sequence are being tested with the aim to develop a completely synthetic surfactant preparation. Nevertheless, the effects of the surfactant proteins on the endogenous surfactant metabolism remain unknown.

Our laboratory has been able to formulate and synthesize SP-B and SP-C peptides, which closely mimic the function of natural surfactant proteins [23]. The in vivo metabolism and the effects on the clearance of these surfactant peptides have not yet been investigated. There- fore, we studied the effect of monomeric and dimeric SP$\mathrm{B}_{1-25}$ peptides, based on the N-terminal segment of human SP-B with an alanine for cysteine substitution at position 11, and SP- $\mathrm{B}_{63-78}$, based on the C-terminal of human SP-B, as well as various mutants of these peptides, on the uptake of surfactant-like liposomes by alveolar type II cells and alveolar macrophages. The SP- $\mathrm{B}_{1-25}$ (Cys$11 \rightarrow$ Ala-11) variant disulfide linked homodimer has been the focus of recent laboratory studies as it closely mimics the in vitro and in vivo functions of the fulllength SP-B protein [24-26].

\section{Materials and Methods}

\section{Ethical Guidelines}

The Institutional Animal Care and Use Committee at the Erasmus MC-Faculty Rotterdam, approved this study.

\section{Native SP-B and Synthetic SP-B Peptides}

Native SP-B was isolated from porcine lung lavage and characterized according to standard procedures [27]. Monomeric SP$B_{1-25}$ peptide was synthesized on a $0.25-\mathrm{mmol}$ scale with a peptide synthesizer (Applied Biosystems Model 431A) using a FastMoc ${ }^{\mathrm{TM}}$ strategy [28]. The SP-B $\mathrm{B}_{1-25}$ sequence was based on the $\mathrm{N}$-terminal of human SP-B [29] with one modification, cysteine in position 11 was replaced by alanine (Cys- $11 \rightarrow$ Ala-11 variant monomer) $[24,25]$. The SP-B ${ }_{63-78}$ sequence was based on the C-terminal of human SP-B [29] without modification (SP-B $63-78$ ) or with substitutions of alanine for cysteine in positions 71 (Cys-71 $\rightarrow$ Ala-71) and 77 (Cys-77 $\rightarrow$ Ala-77) in Ala-SP-B ${ }_{63-78}$. The peptides were synthesized with prederivatized Fmoc-Gly resin (CalbiochemNova, La Jolla, Calif., USA) or PEG-PA resin (Perceptive Biosystems, Old Connecticut Path, Mass., USA) and single coupled for all residues. After purification by reverse-phase high performance liquid chromatography, the molecular mass was confirmed by fast atom bombardment mass spectroscopy or electrospray mass

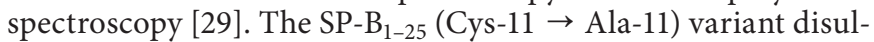
fide linked homodimer was formed by oxidizing the monomeric SP- $B_{1-25}$ peptide $\left(S P-B_{1-25}\right)[24,25]$. The molecular mass of this dimeric SP-B $B_{1-25}$ peptide (dSP-B $B_{1-25}$ ) was confirmed by electro spray mass spectroscopy and indicated the yield of dimeric product to be essentially $100 \%$ [24].

Mutant monomeric and dimeric SP- $\mathrm{B}_{1-25}$ peptides were synthesized with site-specific substitutions of serine for arginine in positions 12 and 17 and for lysine in positions 16 and 24 of the $\mathrm{N}$ terminal (fig. 1). Mutant SP-B $63-78$ peptide was synthesized with site-specific substitutions of serine for arginine in positions 64, 72 , and 76 of the C-terminal (fig. 1) These site-specific substitutions reduce the net cationic charge on the molecule without affecting the hydrophobicity [23]. Synthesis, purification and characterization of the serine mutants were done in the same manner as the original peptides.

\section{Liposome Preparation}

Liposomes were prepared by mixing the following lipids in chloroform:methanol (1:1; v:v); dipalmitoylphosphatidylcholine 
(DPPC), egg phosphatidylcholine (PC), egg phosphatidylglycerol (PG), soybean phosphatidylinositol (PI), and phosphatidyl ethanolamine (PE) labeled with Texas red in the head group (Texas Red DHPE, Molecular Probes Inc., Leiden, The Netherlands), cholesterol in a weight ratio of 55:21:8:2:6:8 and the indicated surfactant proteins at a protein/lipid concentration of $3: 100 \mathrm{w}: \mathrm{w}$. Subsequently, this mixture was dried under a stream of nitrogen. The lipids were purchased from Sigma (Zwijndrecht, The Netherlands), unless stated otherwise. The liposomes were suspended in PBS, $\mathrm{pH} 7.4$, at a concentration of $0.5 \mathrm{mg}$ lipids/ $\mathrm{ml}$ (in vitro experiments) or $1 \mathrm{mg} / \mathrm{ml}$ (in vivo experiments) using glass pearls and vortexing. Immediately prior to use, the liposome suspension was sonicated for $2 \mathrm{~min}$ on ice using an ultrasonic disintegrator (Branson Sonifier 250, Danbury, Conn., USA) to prepare small unilamellar liposomes [4]. The size of the liposomes was determined by dynamic light scattering at $25^{\circ} \mathrm{C}$ with a Malvern 4700 system using a $25 \mathrm{~mW}$ He-Ne laser (NEC, Tokyo, Japan) and the auto measure version 3.2 software (Malvern Ltd., Worcestershire, UK). As a measure of particle size distribution of the dispersion, the system reports a polydispersity index (p.d.). This index ranges from 0.0 for a monodisperse and up to 1.0 for an entirely polydisperse dispersion. After ultrasonification the liposome size ranged from 140 to $165 \mathrm{~nm}$ and the polydispersity index ranged from 0.2 to 0.35 .

\section{Intratracheal Instillation of Fluorescent Liposomes}

The studies were performed with male Sprague-Dawley rats (IFFA Credo, The Netherlands) with a bodyweight of $318 \pm 16 \mathrm{~g}$. After induction of anesthesia with a mixture of nitrous oxide (66\%), oxygen (33\%) and isoflurane (1-2\%), a sterile polyethylene catheter $(0.8 \mathrm{~mm}$ o.d.) was inserted into one of the carotid arteries. The animals were then tracheotomized and a sterile metal cannula was inserted into the trachea. After these surgical procedures, the animals were mechanically ventilated as described [4, 30, 31]. After disconnection from the ventilator, the liposomes were administered intratracheally at the indicated dosage. The suspension of liposomes ( $1 \mathrm{mg}$ lipids $/ \mathrm{ml}$ ) was administered as a bolus of $3 \mathrm{ml} / \mathrm{kg}$ followed by a bolus of air $(12 \mathrm{ml} / \mathrm{kg})$, directly into the endotracheal tube via a syringe, and the animals were immediately reconnected to the ventilator. After $1 \mathrm{~h}$ of ventilation the animals were sacrificed by exsanguination via the abdominal aorta and the alveolar type II cells and alveolar macrophages were isolated to determine the cell-associated fluorescence. Untreated animals were sacrificed immediately after anesthesia and their isolated alveolar type II cells and alveolar macrophages were used to correct for auto-fluorescence.

Isolation of Alveolar Type II Cells and Alveolar Macrophages

The alveolar type II cells and alveolar macrophages were isolated as described $[4,30,31]$ and suspended in cell-buffer $(140 \mathrm{mM}$ $\mathrm{NaCl}, 5 \mathrm{mM} \mathrm{KCl}, 2.5 \mathrm{mM} \mathrm{Na}_{2} \mathrm{HPO}_{4} \cdot 2 \mathrm{H}_{2} \mathrm{O}, 10 \mathrm{~mm}$ HEPES, $6 \mathrm{mM}$ glucose, $2.0 \mathrm{mM} \mathrm{CaCl}_{2}$ and $1.3 \mathrm{mM} \mathrm{MgSO}_{4}$ ) at concentrations of $2 \times 10^{6}$ cells $/ \mathrm{ml}$ and stored on ice until further use. Alveolar macrophages were identified using monoclonal antibodies specific for rat macrophages (ED9) and alveolar type II cells were identified using an alkaline phosphatase assay as described by Edelson et al. [32]. The average yield of alveolar type II cells was $16 \times 10^{6}$ with a purity of $80 \pm 5 \%$ and $5 \times 10^{6}$ alveolar macrophages with a purity of $92 \pm 5 \%$ per rat.

Effect of SP-B Peptides on Uptake by Alveolar Cells
In vitro Uptake of SP-B Peptides

Alveolar cells of untreated animals were isolated as described above and suspended in cell buffer to a concentration of $2 \times 10^{6}$ cells $/ \mathrm{ml}$. A total of $3 \times 10^{5}$ cells were incubated with the indicated concentration of the specified liposomes at $37^{\circ} \mathrm{C}$ (final volume $500 \mu \mathrm{l}$ ) in a shaking water bath. After $1 \mathrm{~h}$, the incubation was terminated by addition of $2 \mathrm{ml}$ of ice-cold PBS $\left(4^{\circ} \mathrm{C}\right)$. The cellsuspension was centrifuged at $100 \mathrm{~g}$ for $10 \mathrm{~min}$ at $4^{\circ} \mathrm{C}$. The supernatant was removed, and the cells were suspended in $2 \mathrm{ml}$ ice-cold PBS and centrifuged again. This wash procedure was repeated twice. Finally, the pellet was resuspended in $200 \mu \mathrm{l}$ of cold PBS, and cell-associated fluorescence was determined as described below.

\section{Flow Cytometry}

Cell-associated fluorescence of the alveolar type II cells and alveolar macrophages as a measure for internalized liposomes was determined using flow cytometry (FACSCalibur; Becton Dickinson, Mountain View, Calif., USA). The mean cell-associated fluorescence was determined of all the cells, including the cells, which did not internalize the fluorescent liposomes. In addition, the mean cell-associated fluorescence was determined of the cells with a fluorescence higher then the autofluorescence (Mean cell-associated fluorescence of gated cells) as described before $[4,30,31]$.

\section{Localization of Cell-Associated Fluorescence}

To localize the cell-associated fluorescence, intracellular or extracellular, confocal laser micrographs were obtained using a confocal microscope (LSM510NLO, Carl Zeiss, Jena, Germany) as described $[4,30,31]$.

\section{Statistical Analysis}

Differences between the groups that received liposomes with a different composition were analyzed using an ANOVA followed by a Bonferroni post-hoc test. Blood gas values were analyzed using a repeated measurement ANOVA. Differences were considered statistically significant at a $p<0.05$. Values are expressed as mean \pm SEM

\section{Results}

\section{Effect of SP-B $B_{1-25}$ on the Uptake of Liposomes by}

Alveolar Cells in vitro

After isolation from untreated animals, alveolar cells were incubated with different concentrations of liposomes. In these liposomes, native SP-B (dSP-B), SP-B $1-25$ or $\mathrm{dSP}-\mathrm{B}_{1-25}$ was included in a protein to lipid ratio of 3:100. After $1 \mathrm{~h}$ the incubation was stopped and cell-associated fluorescence was determined.

The incorporation of SP-B (or derivations) in the fluorescent-labeled liposomes did not influence the uptake of these liposomes by alveolar cells (fig. $2 \mathrm{a}, \mathrm{c}$ ). Nor was the percentage of cells involved in the uptake affected by the inclusion of proteins in the liposome (fig. $2 \mathrm{~d}$ ). 


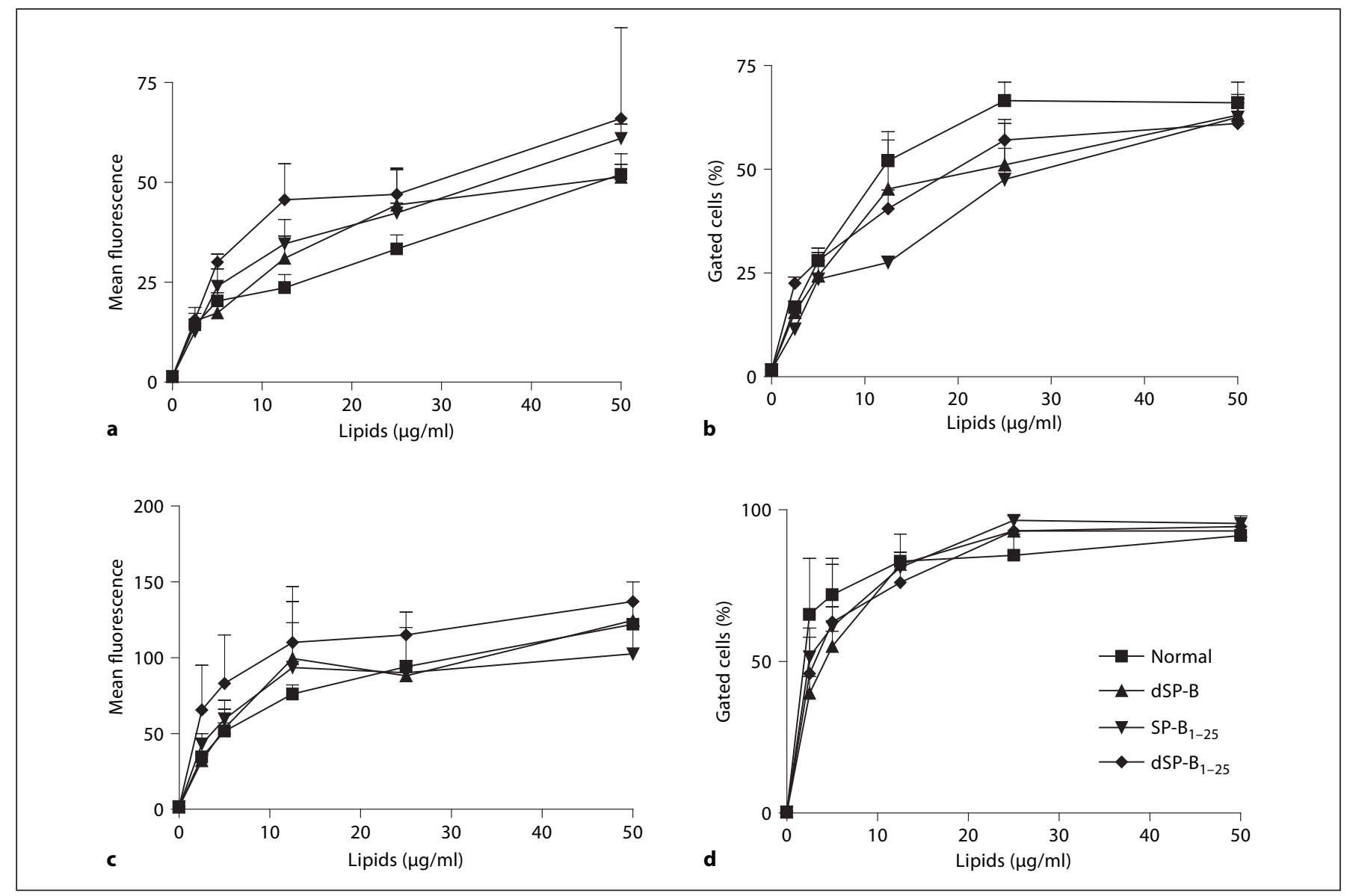

Fig. 2. Effect of $d S P-B, S P-B_{1-25}$ and $d S P-B_{1-25}$ on the alveolar cell uptake in vitro. Alveolar cells were isolated from untreated animals and incubated for 1 hour at $37^{\circ} \mathrm{C}$ with the indicated concentrations of fluorescent liposomes dependent on the group containing native SP-B (dSP-B), monomeric SP- $\mathrm{B}_{1-25}\left(\mathrm{SP}-\mathrm{B}_{1-25}\right)$ or dimeric SP- $B_{1-25}\left(\mathrm{dSP}-\mathrm{B}_{1-25}\right)$ or no proteins (normal). The SP-B proteins were included in a protein to lipid ratio of $3: 100$. The

\section{Effect of SP-B Peptides Containing Liposomes on Gas}

Exchange

The inclusion of $\mathrm{SP}-\mathrm{B}_{1-25}$ and $\mathrm{SP}-\mathrm{B}_{63-78}$ peptides in the labeled liposomes did not affect gas exchange. Arterial blood gas values remained at healthy levels after instillation (results not shown).

\section{Effect of SP-B Peptides on the Uptake by Alveolar}

\section{Cells in vivo}

To study the effect of the various SP-B peptides on the liposome uptake by the alveolar cells, the peptides were incorporated in fluorescent-labeled liposomes at a protein to lipid concentration of 3:100 w:w. The mean cellassociated fluorescence of the gated alveolar cells, the al- mean cell-associated fluorescence of gated alveolar type II cells (a) and alveolar macrophages (c) was determined. In addition, the percentage gated alveolar type II cells (b) and alveolar macrophages (d) were determined. No significant differences were observed at any concentration ( $\mathrm{n}=4$ incubations at every concentration; values are mean \pm SEM).

veolar cells which had internalized the fluorescent liposomes, was significantly higher when either dSP- $\mathrm{B}_{1-25}$ or SP- $\mathrm{B}_{63-78}$ was included in the labeled liposomes suggesting more uptake of these liposomes by the cells (fig. 3a). However, the number of alveolar type II cells involved in the uptake when dSP- $\mathrm{B}_{1-25}$ was incorporated in the liposomes was significantly reduced (fig. $3 \mathrm{~b}$ ). Also a reduction of the number of cells internalizing $\mathrm{SP}_{-} \mathrm{B}_{63-78}$ containing liposomes was observed, though not significant. Overall, the mean uptake of the liposomes by the alveolar type II cells was not affected by the incorporation of SP-B or SP-B peptides in the liposomes (fig. 3a).

The uptake of liposomes by alveolar macrophages is more influenced by the inclusion of SP-B peptides in the 


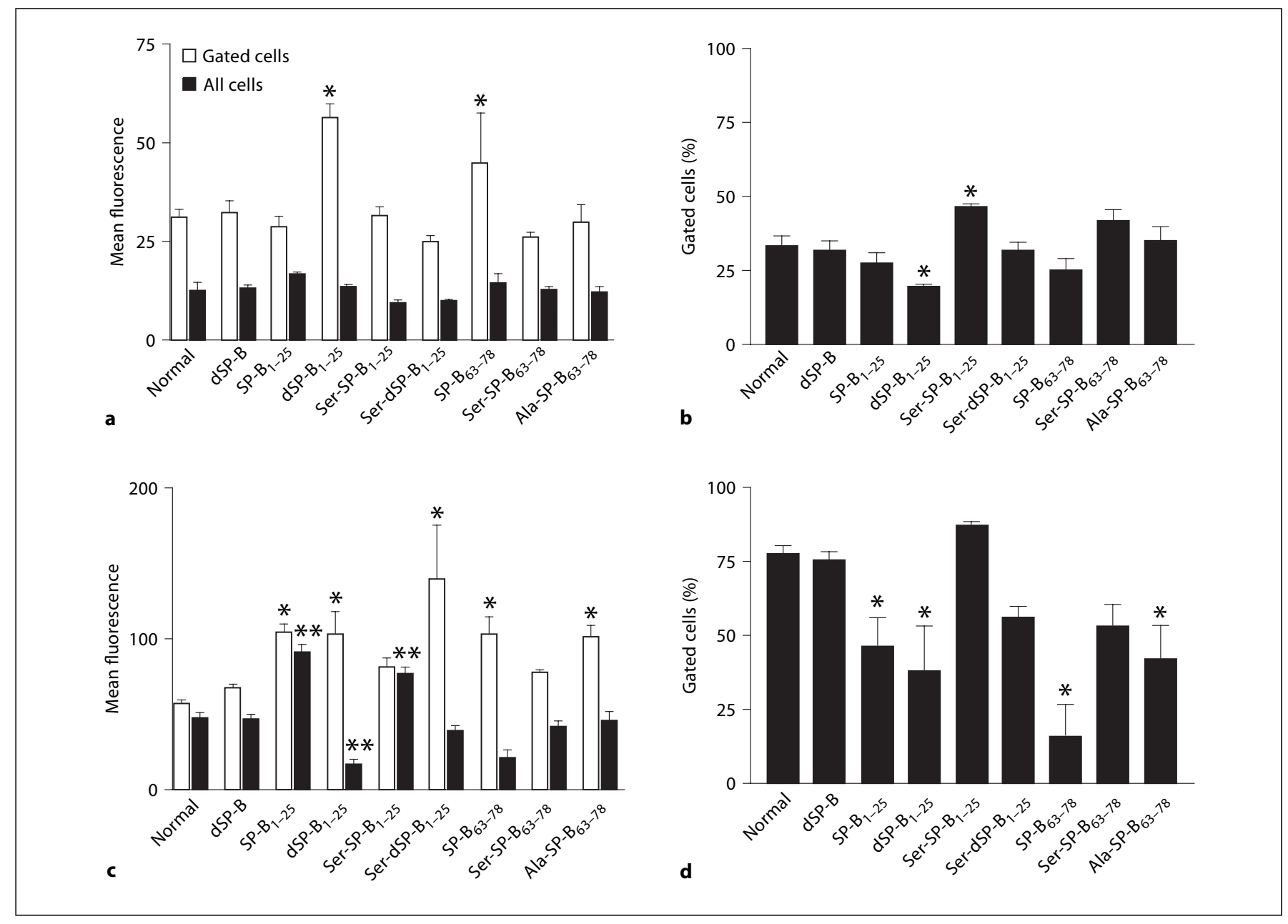

Fig. 3. Effect of SP-B and its peptides on the uptake of liposomes by alveolar cells in vivo. Fluorescent labeled liposomes with no proteins (Normal), native SP-B (dSP-B), monomeric SP-B $\mathrm{B}_{1-25}$ (SP$\left.\mathrm{B}_{1-25}\right)$, dimeric SP-B ${ }_{1-25}\left(\mathrm{~d} S \mathrm{P}-\mathrm{B}_{1-25}\right)$, Ser-SP-B ${ }_{1-25}$, Ser-dSP-B $\mathrm{B}_{1-25}$, monomeric SP-B $63-78$ (SP-B $63-78)$, Ser-SP-B $63-78$ or Ala-SP-B $63-78$ incorporated at a protein to lipid ratio of 3:100 were intratracheally instilled in ventilated rats. After one hour, alveolar type II cells $(\mathbf{a}, \mathbf{b})$ and alveolar macrophages $(\mathbf{c}, \mathbf{d})$ were isolated. The

liposome. Incorporation of mono or dimer SP-B ${ }_{1-25}$, SerSP- $\mathrm{B}_{1-25}$, SP-B $\mathrm{B}_{63-78}$ and Ala-SP-B ${ }_{63-78}$ enhanced the uptake of the liposomes by the gated cells (fig. 3c). The percentage alveolar macrophages taking part in the uptake was significantly decreased with the inclusion of mono or dimer SP-B ${ }_{1-25}$, SP-B $_{63-78}$ and Ala-SP-B ${ }_{63-78}$ in the liposomes (fig. $3 \mathrm{~d}$ ). In contrast to the alveolar type II cells, the total uptake by all the alveolar macrophages was influenced by the SP-B peptides. SP-B ${ }_{1-25}$ and Ser-SP-B ${ }_{1-25}$ stimulated and dSP-B $\mathrm{B}_{1-25}$ inhibited the uptake (fig. $3 \mathrm{C}$ ).

Effect of SP-B Peptides on Uptake by Alveolar Cells mean cell-associated fluorescence of all the cells was determined (all cells, closed bars; a, c) as well as the mean cell-associated fluorescence of those cells with a higher fluorescence then the autofluorescence (gated cells, open bars; a, c). In addition, the number of cells was measured with a higher fluorescence then the autofluorescence (gated cells [\%]; b, d) ( $n=4$ rats per group; values are mean \pm SEM $) ;{ }^{*} \mathrm{p}<0.05$ versus normal; ${ }^{* *} \mathrm{p}<0.05$ versus normal (total fluorescence).

\section{Localization of Cell-Associated Fluorescence Caused by $S P-B_{1-25}$}

To ascertain that the cell-associated fluorescence was located within the cell rather than binding to the outer membrane of the cell, confocal laser scanning microscopy was used. One hour after intratracheal instillation of the liposomes containing SP-B $\mathrm{B}_{1-25}$ or dSP- $\mathrm{B}_{1-25}$ in ventilated rats, the alveolar cells were isolated and confocal scans were made. These confocal scans through the middle of the cell show a punctuate fluorescence throughout the cell limited to its circumference with the exception of 

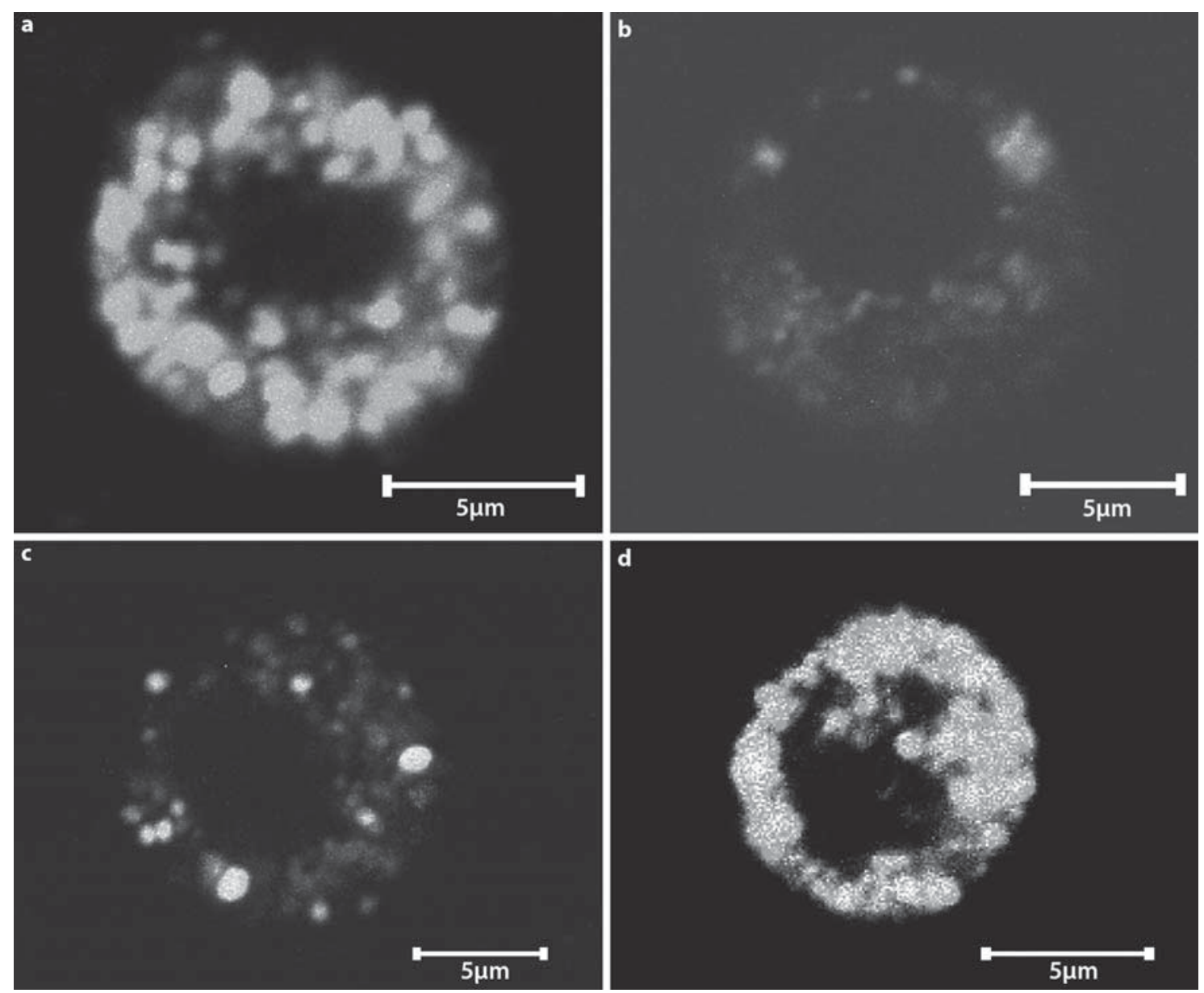

Fig. 4. Localization of cell-associated fluorescence of $S P-B_{1-25}$. Mechanically ventilated rats were intratracheally instilled with fluorescent labeled liposomes containing either SP-B $\mathrm{B}_{1-25}(\mathbf{a}, \mathbf{c})$ or d-SP-B $1-25$ (b, d). One hour after instillation alveolar macrophages $(\mathbf{c}, \mathbf{d})$ and alveolar type II cells $(\mathbf{a}, \mathbf{b})$ were isolated and confocal scans were made. All scans were made using the same microscopic settings.

its nucleus, demonstrating the intracellular presence of the fluorescent liposomes (fig. 4); although these figures suggest a different uptake or distribution, because there are differences in density of luminance and size of the granulae no definite conclusion can be drawn from the current experiments. Similar results were obtained with mono and dimer Ser-SP-B ${ }_{1-25}$ (results not shown).

\section{Discussion}

SP-B is essential for the biophysical properties of pulmonary surfactant. SP-B is a 79 amino acid, cysteine-rich hydrophobic protein found in pulmonary surfactant as an $18-\mathrm{kDa}$ dimer. It is synthesized in the endoplasmic re- ticulum of the alveolar type II cell as a large precursor protein of $42 \mathrm{kDa}$. This precursor SP-B is transported via the Golgi complex and the multivesicular bodies to the lamellar bodies while it undergoes proteolytic processing to the mature $9-\mathrm{kDa}$ protein. In the lamellar bodies SP-B combines with the other surfactant proteins and lipids. The lamellar bodies are secreted into the alveolar space, where they provide functional surfactant for the air-water interface. The surfactant metabolism in vivo has recently been reviewed [33]. In the adult lung SP-B is cleared more rapidly from the alveoli than saturated phosphatidylcholine [34]. In the developing lung, the clearance of phospholipids and SP-A is in general much slower than in the adult lung $[35,36]$. The clearance of SP-A, B, and $C$ has been studied in adult (rabbit) lungs $[34,35,37]$, 
the clearance of SP-B in newborn rabbits [38] and that of $\mathrm{SP}-\mathrm{C}$ in preterm lambs [39]. The surfactant proteins are not only cleared from the alveolar space but may also play a role in the clearance of surfactant lipids from the alveolar space. Both SP-A and SP-C have been shown to stimulate the uptake. The effects of SP-B are more complex, at physiological amounts it does not affect uptake though at high concentrations SP-B stimulates the clearance of labeled liposomes [31].

In our laboratory, synthetic peptides of SP-B have been designed, and their function in lowering surface tension has been demonstrated [24]. However, the effects of these synthetic SP-B peptides on the clearance are not yet clarified. In the current study the effect of the incorporation of SP-B peptides on the uptake of labeled liposomes was studied both in vivo and in vitro.

First, the effects of the synthetic SP-B fragments on the uptake of labeled liposomes were studied in vitro and after comparison with native SP-B, it can be concluded that the incorporation of 3\% SP-B or SP-B peptides does not influence the uptake by alveolar cells nor the percentage of cells involved in the uptake. However, significant differences between in vitro and in vivo studies have been demonstrated, and thus similar experiments were performed in vivo.

For alveolar type II cells the overall clearance of liposomes was the same irrespective of the SP-B peptides it contained. However, individual differences were observed in the two components of the total uptake: (1) the mean fluorescence of the gated cells, and (2) the number of cells involved in the uptake. For instance, inclusion of either dSP- $\mathrm{B}_{1-25}$ or $\mathrm{SP}-\mathrm{B}_{63-78}$ enhanced the mean uptake of the gated cells whereas the number of gated cells was reduced. Only $30 \%$ of the isolated type II cells contained liposomes as was observed before [4]. It is possible that there are local factors which influence the uptake of liposomes by the type II cells or that there are different sub-populations of type II cells in vivo [4]. A population of approximately $30 \%$ of type II cells which can internalize liposomes. This population can vary a little dependent on the composition of the liposome. In vitro, many more type II cells can internalize liposomes and the peptides did not influence the uptake. A possible explanation for the differences in vivo and in vitro is that the uptake of liposomes by the alveolar type II cells is tightly regulated by cells or components of the alveolar compartment in vivo as we postulated before $[4,40]$. Also for alveolar macrophages the uptake of liposomes in vitro and in vivo was different. In vitro, the inclusion of SP-B or the SP-B peptides in the liposomes did not influence the uptake. In vivo, all the peptides, except
Ser-SP-B ${ }_{63-78}$ and Ser-SP-B ${ }_{1-25}$, enhanced the uptake of the liposomes per gated cell. The number of cells involved in the uptake was reduced when mono or dimer SP- $\mathrm{B}_{1-25}$, SP- $\mathrm{B}_{63-78}$ or Ala-SP-B $\mathrm{B}_{63-78}$ were included in the liposome. SP- $\mathrm{B}_{1-25}$ and Ser-SP- $\mathrm{B}_{1-25}$ enhanced the total uptake by the alveolar macrophages whereas d-SP-B $\mathrm{B}_{1-25}$ reduced it.

Unfortunately, a simple relation between the structure of the SP-B peptides and the uptake of liposomes containing these peptides by the alveolar cells cannot be demonstrated. SP- $\mathrm{B}_{1-25}$ contains an Ala for Cys-11 substitution resulting in a more saposine-like fold which is present in the native full-length SP-B structure [40]. It seems unlikely that the saponine-like fold plays a crucial role in the uptake, since SP- $\mathrm{B}_{1-25}$ and native SP-B both have the saposine fold but have a different effect on the uptake. Also alterations in the cationic charge of SP-B by the substitutions of either serine for arginine and lysine or alanine for cysteine, the mono or dimer form of the peptides and the $\mathrm{N}$-terminus or C-terminus of SP-B, do not by themselves govern the uptake of the liposomes. More studies are therefore required to determine the exact mechanism by which the SP-B peptides influence the uptake of liposomes by alveolar cells as well as the intracellular route of the liposomes.

These synthetic surfactant proteins, based on human native SP-B were developed with the aim to produce a completely synthetic surfactant. Charge of the SP-B peptides, mono or dimeric form, the saponine-like fold were shown to influence the surface-lowering properties of surfactant as well as its resistance to inactivation by serum components [40]. The results of the current study indicate that native SP-B and its peptides tested had no effect on the overall uptake of liposomes by alveolar type II cells, an important aspect of the surfactant metabolism. Therefore, as far as the uptake is concerned, there seems to be no preference of one particular peptide over the other to use in synthetic surfactant. However the clearing of the SP-B peptides by alveolar macrophages, which may determine the half-life of these peptides in the alveoli, is influenced by the structure of the SP-B peptides. Turnover studies using the different SP-B peptides are required to determine how long the peptides stay in the alveolar compartment.

\section{Acknowledgments}

The authors thank Laraine Visser-Isles for English-language editing. Supported by National Institutes of Health grant HL55534 (F.J.W., A.J.W.). 


\section{References}

1 Veldhuizen RA, Marcou J, Yao LJ, McCaig L, Ito Y, Lewis JF: Alveolar surfactant aggregate conversion in ventilated normal and injured rabbits. Am J Physiol 1996;270:L152-L158.

-2 Magoon MW, Wright JR, Baritussio A, Williams MC, Goerke J, Benson BJ, Hamilton RL, Clements JA: Subfractionation of lung surfactant. Implications for metabolism and surface activity. Biochim Biophys Acta 1983; 750:18-31.

$\checkmark 3$ Yamada T, Ikegami M, Jobe AH: Effects of surfactant subfractions on preterm rabbit lung function. Pediatr Res 1990;27:592598.

4 Poelma DL, Zimmermann LJ, Scholten HH, Lachmann B, van Iwaarden JF: In vivo and in vitro uptake of surfactant lipids by alveolar type II cells and macrophages. Am J Physiol 2002;283:L648-L654.

5 Dobbs LG, Wright JR, Hawgood S, Gonzalez $\mathrm{R}$, Venstrom K, Nellenbogen J: Pulmonary surfactant and its components inhibit secretion of phosphatidylcholine from cultured rat alveolar type II cells. Proc Natl Acad Sci USA 1987;84:1010-1014.

6 Rice WR, Ross GF, Singleton FM, Dingle S, Whitsett JA: Surfactant-associated protein inhibits phospholipid secretion from type II cells. J Appl Physiol 1987;63:692-698.

7 Kuroki Y, Mason RJ, Voelker DR: Pulmonary surfactant apoprotein A structure and modulation of surfactant secretion by rat alveolar type II cells. J Biol Chem 1988;263: 3388-3394.

8 Bates SR, Dodia C, Fisher AB: Surfactant protein A regulates uptake of pulmonary surfactant by lung type II cells on microporous membranes. Am J Physiol 1994;267: L753-L760.

9 Horowitz AD, Moussavian B, Han ED, Baatz JE, Whitsett JA: Distinct effects of SP-A and SP-B on endocytosis of SP-C by pulmonary epithelial cells. Am J Physiol 1997;273:L159L171.

10 Horowitz AD, Moussavian B, Whitsett JA: Roles of SP-A, SP-B, and SP-C in modulation of lipid uptake by pulmonary epithelial cells in vitro. Am J Physiol 1996;270:L69-L79.

11 Tsuzuki A, Kuroki Y, Akino T: Pulmonary surfactant protein A-mediated uptake of phosphatidylcholine by alveolar type II cells. Am J Physiol 1993;265:L193-L199.

12 Stevens PA, Wissel H, Zastrow S, Sieger D, Zimmer KP: Surfactant protein A and lipid are internalized via the coated-pit pathway by type II pneumocytes. Am J Physiol 2001; 280:L141-L151.

13 Wright JR, Youmans DC: Degradation of surfactant lipids and surfactant protein A by alveolar macrophages in vitro. Am J Physiol 1995;268:L772-L780.
14 Rice WR, Sarin VK, Fox JL, Baatz J, Wert S, Whitsett JA: Surfactant peptides stimulate uptake of phosphatidylcholine by isolated cells. Biochim Biophys Acta 1989;1006:237245.

15 Bates SR, Beers MF, Fisher AB: Binding and uptake of surfactant protein B by alveolar type II cells. Am J Physiol 1992;263:L333L341.

16 Bates SR, Fisher AB: Degradation of surfactant protein B by alveolar type II cells. Am J Physiol 1993;265:L448-L455.

17 Sane AC, Young SL: The stimulation of cellular phospholipid uptake by surfactant apoproteins. Biochim Biophys Acta 1994;1213: 107-112.

18 Curstedt T, Jornvall H, Robertson B, Bergman T, Berggren P: Two hydrophobic lowmolecular-mass protein fractions of pulmonary surfactant. Characterization and biophysical activity. Eur J Biochem 1987;168: 255-262.

19 Revak SD, Merritt TA, Degryse E, Stefani L, Courtney M, Hallman M, Cochrane CG: Use of human surfactant low molecular weight apoproteins in the reconstitution of surfactant biologic activity. J Clin Invest 1988;81: 826-833.

20 Glasser SW, Burhans MS, Korfhagen TR, Na CL, Sly PD, Ross GF, Ikegami M, Whitsett JA: Altered stability of pulmonary surfactant in SP-C-deficient mice. Proc Natl Acad Sci USA 2001;98:6366-6371.

21 Stahlman MT, Gray MP, Falconieri MW, Whitsett JA, Weaver TE: Lamellar body formation in normal and surfactant protein Bdeficient fetal mice. Lab Invest 2000;80:395403.

22 Tokieda K, Whitsett JA, Clark JC, Weaver TE, Ikeda K, McConnell KB, Jobe AH, Ikegami M, Iwamoto HS: Pulmonary dysfunction in neonatal SP-B-deficient mice. Am J Physiol 1997;273:L875-L882.

23 Walther FJ, Hernandez-Juviel J, Bruni R, Waring AJ: Protein composition of synthetic surfactant affects gas exchange in surfactant-deficient rats. Pediatr Res 1998;43:666673.

24 Veldhuizen EJ, Waring AJ, Walther FJ, Batenburg JJ, van Golde LM, Haagsman HP: Dimeric N-terminal segment of human surfactant protein B (dSP-B(1-25)) has enhanced surface properties compared to monomeric SP-B(1-25). Biophys J 2000;79: 377-384.

25 Walther FJ, Hernandez-Juviel JM, Gordon LM, Sherman MA, Waring AJ: Dimeric surfactant protein $B$ peptide $\mathrm{sp}-\mathrm{b}(1-25)$ in neonatal and acute respiratory distress syndrome. Exp Lung Res 2002;28:623-640.
26 Walther FJ, Hernandez-Juviel JM, Mercado PE, Gordon LM, Waring AJ: Surfactant with SP-B and SP-C analogues improves lung function in surfactant-deficient rats. Biol Neonate 2002;82:181-187.

27 Oosterlaken-Dijksterhuis MA, Haagsman HP, van Golde LM, Demel RA: Characterization of lipid insertion into monomolecular layers mediated by lung surfactant proteins SP-B and SP-C. Biochemistry 1991;30: 10965-10971.

-28 Fields CG, Lloyd DH, Macdonald RL, Otteson KM, Noble RL: HBTU activation for automated Fmoc solid-phase peptide synthesis. Pept Res 1991;4:95-101.

29 Bank PD: Research collaboratory for Structural Bioinformatics. PDB ID \#1 DFW: http://www.rcsb.org.

30 Poelma D, Lachmann B, Haitsma JJ, Zimmermann LJ, van Iwaarden J: Influence of phosphatidylglycerol on the uptake of liposomes by alveolar cells and on lung function. J Appl Physiol 2005;98:1784-1791.

31 Poelma DL, Zimmermann LJ, van Cappellen WA, Haitsma JJ, Lachmann B, van Iwaarden JF: Distinct effects of SP-B and SP-C on the uptake of surfactant-like liposomes by alveolar cells in vivo and in vitro. Am J Physiol 2004;287:L1056-L1065.

32 Edelson JD, Shannon JM, Mason RJ: Alkaline phosphatase: a marker of alveolar type II cell differentiation. Am Rev Respir Dis 1988; 138:1268-1275

33 Ikegami M, Jobe AH: Surfactant protein metabolism in vivo. Biochim Biophys Acta 1998;1408:218-225.

34 Ueda T, Ikegami M, Henry M, Jobe AH: Clearance of surfactant protein B from rabbit lungs. Am J Physiol 1995;268:L636L641.

35 Ueda T, Ikegami M, Jobe AH: Clearance of surfactant protein A from rabbit lungs. Am J Respir Cell Mol Biol 1995;12:89-94.

36 Ikegami M, Jobe A, Yamada T, Priestly A, Ruffini L, Rider E, Seidner S: Surfactant metabolism in surfactant-treated preterm ventilated lambs. J Appl Physiol 1989;67:429437.

37 Ikegami M, Horowitz AD, Whitsett JA, Jobe $\mathrm{AH}$ : Clearance of SP-C and recombinant SP$\mathrm{C}$ in vivo and in vitro. Am J Physiol 1998;274: L933-L939.

38 Henry M, Ikegami M, Ueda T, Jobe A: Surfactant protein B metabolism in newborn rabbits. Biochim Biophys Acta 1996;1300: 97-102.

39 Ikegami M, Jobe AH: Surfactant protein-C in ventilated premature lamb lung. Pediatr Res 1998;44:860-864.

40 Walther FJ, Gordon LM, Zasadzinski JA, Sherman MA, Waring AJ: Surfactant protein B and C analogues. Mol Genet Metab 2000; 71:342-351. 